science or technology, or in industrial design. The grants are to be awarded by the trustees of the Plasties Industry Education Fund and will be made for periods of one year at a time. The value of the grants will normally be of the order of $£ 100$. Applications must be submitted in writing to the Secretary, Plastics Institute, 6 Mandeville Place, London, W.1, by July 15 .

\section{International Conference on High-Energy Physics}

THE tenth annual international conference on "High-Energy Physics" is to be held at the University of Rochester during August 25-Soptember 1. The Conforence has been authorized by the Commission on High Enorgy Physies of the International Union of Pure and Applied Physics. Other sponsors aro the U.S. National Academy of Sciences, the U.S. National Science Foundation, the U.S. Atomic Energy Commission, Office of Ordnance Research and a number of industrial organizations. Approximately 175 delegates from more than 30 countries will actend the conference including India, Australia, Sweden, Brazil, Pakistan, Israel, Mexico, Turkey, Yugoslavia, Argentina, Poland and Greece. The U.S.S.R. has signified its intontion of sending a 40-man delegation. One of the most important aspects of the Conference will be the first official reports on activities of the new $25 \times 10^{9}-\mathrm{eV}$. accelerator at the European Centre for Nuclear Research in Geneva. The chairman of the Conference is Prof. Robert E. Marshak, chairman of the Dopartment of Physics and Astronomy, University of Rochester, and also secrotary of tho organizing committee, and from whom further information ean be obtained.

\section{Biology of Space Travel}

THE Institute of Biology is arranging a symposium to consider various biological problems connected with space travel. It will be held during September 29-30, and the topics to be considered will include : the possible existence of some form of life on other planets; the danger of contamination of other planets and the Earth by space vehicles; effects of high and extremely low gravitational forces on the human body; the effocts on man of radiation in space ; maintenance of life in space ships ; psychological problems connected with the choice of personnel for conditions of solitude and confinoment. Further information can be obtained from the Goneral Secretary, Institute of Biology, 41 Queen's Gate, London, S.W.7.

\section{Announcements}

THE following have been elected officers for the year 1960-61 of the Salters' Company : Master, Mr. R. S. H. Callingham; Upper Warden, Sir Alexander Todd; Second Warden, Mr. T. G. Hicks.

DR. W. R. Aykroyd, senior lecturer in the Department of Human Nutrition at the London School of Hygiene and Tropical Medicine, and recently director of the Nutrition Division of the Food and Agriculture Organization of the United Nations, has been made an honorary member of the American Institute of Nutrition.

THE United Nations Educational, Scientific and Cultural Organization Centre for Scientific Cooperation in Latin America, Montevideo, has issued as Vol. 4 of "Scientific Institutions and Scientists in Latin America" a list of scientific institutions of
Argentine (pp. vi+136. Montevideo: Unesco, Centro de Co-operacion Cientifica para America Latina, 1959).

The seventeenth International Congress of Pure and Applied Chemistry is to be held in Munich during August 26-29. Further information can be obtained from the secretary-general of the International Union of Pure and Applied Chemistry, Dr. R. Morf, e/o Sandoz, S.A., Basle 13.

The fifth World Forestry Congress, organized by the Government of the United States and sponsored by the Food and Agriculture Organization, will be held in Seattle, Washington, during August 29September 16. Further information can be obtained from Dean Hardy L. Shirley, State University College of Forestry at Syracuse University, Syracuse 10, N.Y.

During August 29-September 9 the "Association des Cours Internationaux de Lyophilization" will be holding the second international course on "Lyophilization" at the Institute National des Sciences Appliquées in Lyons. Further information can be obtained from Dr. Louis R. Rey, Laboratoire de Physiologie, Ecole Normale Supérieure, 24 rue Ihomond, Paris 5e.

UNDER the auspices of the International Federation of Electron Microscope Societies, the Nederlandse Vereniging voor Electronenmicroscopie is organizing a European regional conference on "Electron Microscopy". This is to be held at Delft during August 28-Soptember 3. Further information can bo obtained from A. L. Houwink, secretariat of the European Regional Conference on Electron Microscopy, Julianalaan 67a, Delft.

THe first International Pharmacological Meeting is to be held in Stockholm during August 22-25, 1961. The meeting is to be held under the auspices of the Section of Pharmacology of the International Union of Physiological Sciences. Further information can be obtained from the secretary-general, A. Wretlind, First International Pharmacological Meeting, Karolinska Institutet, Stockholm 60.

The first International Congress of Histochemistry and Cytochemistry is to be held in Paris during August 28-September 3. The Congress is organized under the auspices of the Société Française d'Histochimie in collaboration with histochemical societies in many other countries. Further information can be obtained from the secretary-general, Dr. R. Wegmann, First International Congress of Histochemistry and Cytochemistry, 45 rue des SaintsPères, Paris 6 e.

The Czechoslovak Academy of Science is to organize an international conference on "Semiconductor Physics" at Prague during August 29-September 2 , under the auspices of the International Union for Pure and Applied Physics, and which will continue the series of conferences held in Reading (1950), Amsterdam (1954), Garmisch-Partenkirchen (1956) and Rochester (1958). Further information can be obtained from Dr. Miloš Matyáš, Institute of Technical Physics, Prague 5, Cakrovarnická 10, Czechoslovakia.

Erratum. Mr. M. W. Hardisty, writing with reference to the communication "Sex Ratio of Ammocoetes" in Nature of June 18, p. 988, states that the symbols $\delta$ and $q$ should be reversed. 